\title{
Mild Reductive Cleavage of Tryptophan and Histidine Side-Chain Protecting Groups
}

\author{
Hernani L. S. Maia, ${ }^{[a]}$ Luís S. Monteiro, ${ }^{*[a]}$ and Joana Sebastião ${ }^{[a]}$
}

Keywords: Protecting groups / Cyclic voltammetry / Reductions / Cleavage reactions

The activation potentials of the p-toluenesulfonyl and benzoyl groups as determined by cyclic voltammetry when they are linked to indole or imidazole are less negative than when these groups are linked to aliphatic amines. This makes them most suitable for side-chain protection of trypto- phan and histidine, as it allows mild selective cleavage not only by controlled-potential electrolysis but also by chemical reduction using either magnesium in anhydrous methanol or mercury-activated aluminum.

\section{Introduction}

The synthesis of tryptophan- or histidine-containing peptides usually requires the use of side-chain protection to prevent undesirable side reactions occurring at these moieties. $^{[1,2]}$ In the case of tryptophan, the unprotected indole nucleus is highly sensitive to electrophilic attack and oxidation, namely tert-butylation when tert-butyloxycarbonyl groups or tert-butyl esters are removed by TFA or HF, ${ }^{[3]}$ whilst $N^{i m}$-unprotected histidine is liable to racemization ${ }^{[4]}$ and cyclisation ${ }^{[5]}$ (formation of imidazolides). Cyclic voltammetry studies of $N$-protected indole and imidazole have shown that their $p$-toluenesulfonyl (tosyl) ${ }^{[6]}$ and (dimethylamino)sulfony ${ }^{[7]}$ derivatives have cathodic potentials shifted by over $0.5 \mathrm{~V}$ as compared to aliphatic sulfonamides. We found that this shift allows 1-tosylindole to be cleaved rapidly and completely by magnesium in anhydrous methanol. ${ }^{[8]}$ As many of the groups used for side-chain protection of tryptophan and histidine are cleaved by reductive methods, ${ }^{[9,10]}$ the above results prompted us to prepare and investigate the cyclic voltammetry behaviour and selective cleavage of several derivatives of these amino acids sidechain-protected with tosyl or benzoyl groups.

\section{Results and Discussion}

A comparison of the data obtained by cyclic voltammetry of compounds $\mathbf{1 a}$ and $\mathbf{1 b}$ (Table 1) shows that in tryptophan derivatives, the tosyl group bonded to the side-chain nitrogen atom has a $0.36 \mathrm{~V}$ less negative activation potential than that linked to the $\alpha$-amine function. An even larger difference $(0.61 \mathrm{~V})$ was observed for the case of the corresponding histidine derivatives $\mathbf{2} \mathbf{a}$ and $\mathbf{2} \mathbf{b}$. The peak potential for the $N^{\text {in }}$-benzoyl group of tryptophan (1d) is also signific-

\footnotetext{
[a] Department of Chemistry, University of Minho, Gualtar, 4700-320 Braga, Portugal Fax: (internat.) + 351-253/678983 E-mail: monteiro@quimica.uminho.pt

Supporting Information for this article is available on the
} WWW under http://www.eurjoc.com or from the author. antly high $(0.55 \mathrm{~V})$ when compared to that for the $N^{\alpha}$ benzoyl group $(\mathbf{1 c})$. This value is again higher $(0.64 \mathrm{~V})$ in the corresponding derivatives of histidine (compounds $\mathbf{2 c}$ and 2d). Nevertheless, as would be expected from our previous studies on cyclic voltammetry of urethane-type protecting groups ${ }^{[11]}$ in the case of the $p$-nitrobenzyloxycarbonyl group $\left[\mathrm{Z}\left(\mathrm{NO}_{2}\right)\right]$ significantly smaller differences are found, viz. $0.15 \mathrm{~V}$ in the case of tryptophan (compounds 1e and 1f) and $0.22 \mathrm{~V}$ in that of histidine (compounds $\mathbf{2 e}$ and $\mathbf{2 f}$ ).

The fairly high peak potentials found for all groups when protecting the side chain of both tryptophan and histidine suggest that in addition to reductive cleavage by controlledpotential electrolysis, all groups could also be cleaved by selective reduction with an appropriate metal, chosen according to the value of its activation potential (Table 2).

As the activation potentials found for all $N^{i n_{-}}$and $N^{i m_{-}}$ protecting groups were less negative than $-2.3 \mathrm{~V}$ vs. a standard calomel electrode (S.C.E.), reductive cleavage with magnesium in anhydrous methanol $(\mathrm{Mg} / \mathrm{MeOH})$ was attempted for all compounds. High yields (Table 2) of deprotected product were obtained (usually above 90\%) except for cleavage of the $\mathrm{Z}\left(\mathrm{NO}_{2}\right)$ group (compounds $\mathbf{1 f}$ and $\mathbf{2 f}$ ). In the latter case a complex mixture was obtained possibly due to further reduction of the nitro moiety. ${ }^{[12]} \mathrm{The} \mathrm{Z}\left(\mathrm{NO}_{2}\right)$ group in both tryptophan and histidine, and the benzoyl group in the histidine side-chain protection have activation potentials less negative than $-1.7 \mathrm{~V}$ vs. S.C.E., which would enable cleavage with mercury activated aluminum $(\mathrm{Al} / \mathrm{Hg})$. Thus, for compounds $\mathbf{1 f}, \mathbf{2 f}, \mathbf{2 d}$ and $\mathbf{2 h}$ yields in deprotected product were obtained by the $\mathrm{Al} / \mathrm{Hg}$ method within the range $85-96 \%$. In addition, the benzoyl group could also be removed by 2-(diethylamino)ethylamine (DEAEA) induced aminolysis as described previously for acylcarbamates. $^{[13]}$

Differences in the activation potentials of a magnitude similar to that observed between $\alpha$-amine and side-chainprotected compounds, i.e. for the pairs of compounds $\mathbf{1 a} /$ $\mathbf{1 b}, \mathbf{1 c} / \mathbf{1 d}, \mathbf{2} \mathbf{a} / \mathbf{2} \mathbf{b}$ and $\mathbf{2 c / 2 d}$, were the basis for selective electrolytic cleavage of one of the tosyl groups of ditosylated, 
Table 1. Cyclic-voltammetry peak potentials for tryptophan and histidine derivatives

\begin{tabular}{lccc}
\hline No. & Compound & $\begin{array}{c}-E p \text { (vs. S.C.E.) [V] }]^{[\mathrm{a}]} \\
\text { Side-chain protecting group }\end{array}$ & $\alpha$-Amine protecting group \\
\hline $\mathbf{1 a}$ & Tos-Trp-OMe & - & 2.39 \\
$\mathbf{1 b}$ & Boc-Trp(Tos)-OMe & 2.03 & - \\
$\mathbf{1 c}$ & Bz-Trp-OMe & - & - \\
$\mathbf{1 d}$ & Boc-Trp(Bz)-OMe & 1.91 & 1.12 \\
$\mathbf{1 e}$ & Z(NO2)-Trp-OMe & - & - \\
$\mathbf{1 f}$ & Boc-Trp[Z(NO)]-OMe & 0.97 & 2.60 \\
$\mathbf{1 g}$ & Tos-Trp(Tos)-OMe & 2.07 & 2.46 \\
$\mathbf{1 h}$ & Bz-Trp(Bz)-OMe & 1.89 & - \\
$\mathbf{2 a}$ & Tos-His-OMe & 1.85 & - \\
$\mathbf{2 b}$ & Boc-His(Tos)-OMe & - & 2.32 \\
$\mathbf{2 c}$ & Bz-His-OMe & 1.68 & - \\
$\mathbf{2 d}$ & Boc-His(Bz)-OMe & - & -1.13 \\
$\mathbf{2 e}$ & Z(NO2)-His-OMe & 0.91 & - \\
$\mathbf{2 f}$ & Boc-His[Z(NO2)]-OMe & 1.87 & 2.51 \\
$\mathbf{2 g}$ & Tos-His(Tos)-OMe & 1.65 & 2.50 \\
$\mathbf{2 h}$ & Bz-His(Bz)-OMe & & \\
\hline
\end{tabular}

[a] Cathode: vitreous carbon; solvent: DMF; supporting electrolyte: $\mathrm{Bu}_{4} \mathrm{NBF}_{4}\left(0.1 \mathrm{~mol} \mathrm{dm}^{-3}\right)$; substrate conc.: ca. $0.005 \mathrm{~mol} \mathrm{dm}{ }^{-3}$.

Table 2. Yields in cleavage of side-chain protecting groups of tryptophan and histidine derivatives

\begin{tabular}{ccccc}
\hline Compound $^{[\mathrm{a}]}$ & \multicolumn{5}{c}{ Yield [\%] } \\
& By $-E p$ & By Mg/MeOH & By Al/Hg & By DEAEA \\
\hline $\mathbf{1 b}$ & 84 & 98 & - & - \\
$\mathbf{1 d}$ & 77 & 93 & - & 92 \\
$\mathbf{1 f}$ & 74 & - & 96 & - \\
$\mathbf{1 g}$ & 74 & 90 & - & - \\
$\mathbf{1} \mathbf{h}$ & 72 & 81 & - & 94 \\
$\mathbf{2 b}$ & 63 & 83 & - & - \\
$\mathbf{2 d}$ & 87 & 91 & 87 & 63 \\
$\mathbf{2 f}$ & 70 & - & 94 & - \\
$\mathbf{2 g}$ & 81 & 89 & - & - \\
$\mathbf{2}$ & 87 & 83 & 85 & 90 \\
\hline
\end{tabular}

[a] Pure nonrecrystallised material.

mixed primary/secondary diamines. ${ }^{[14]}$ These differences between tosylamides and the corresponding tert-butyl tosylcarbamates also seem to explain why only the latter can be cleaved by magnesium in anhydrous methanol. Thus, it is noteworthy that the side-chain tosyl group of compounds $1 \mathrm{~g}$ and $\mathbf{2 g}$ could be cleaved selectively with regard to their $\alpha$-amine tosyl group by both electrolysis and magnesium in anhydrous methanol (Table 2). The same applies to the case of selective removal of benzoyl from the side chain of compounds $\mathbf{1 h}$ and $\mathbf{2 h}$. In addition, for the latter two compounds selective cleavage with DEAEA was also possible, whilst for $\mathbf{2 h ~ A l / H g - m e d i a t e d ~ s e l e c t i v e ~ s i d e - c h a i n ~ c l e a v a g e ~}$ was equally successful.

These results reinforce our previously made prediction that milder, more selective reductive conditions are possible for ordinary sulfonamides and other similarly protected compounds whose electron affinity can be evaluated by cyclic voltammetry ${ }^{[15]}$ as it is now shown for compounds of the type reported above. In addition, our results offer a new approach for side-chain protection allowing mild deprotection of tryptophan and histidine. This may be useful in the stepwise synthesis of peptides when a nitrobenzyl ester strategy is adopted in connection with the nitrobenzyloxycarbonyl group for amine blocking at the last step, as all these protections can then be removed in a single reaction at the end of the synthesis. Electrolysis may become particularly useful as it is cheap, nonpolluting and easy to scale up. ${ }^{[12]}$

\section{Experimental Section}

General: All melting points were determined with a Gallenkamp melting point apparatus and are uncorrected. TLC analyses were carried out on $0.25 \mathrm{~mm}$ thick precoated silica plates (Merck Fertigplatten Kieselgel $60 \mathrm{~F}_{254}$ ) and spots were visualized under UV light by exposure to vaporised iodine or by spraying with ninhydrin. Preparative chromatography was carried out on Merck Kieselgel 60 (230-400 mesh). - ${ }^{1} \mathrm{H}$ NMR spectra were recorded with a Varian 300 spectrometer in ca. $5 \% \mathrm{CDCl}_{3}$ solutions at $25^{\circ} \mathrm{C}$, when not otherwise stated. All shifts are given in ppm using $\delta_{\mathrm{H}}\left(\mathrm{Me}_{4} \mathrm{Si}\right)=$ 0 as reference. $J$ values are given in $\mathrm{Hz}$. Assignments were made by comparison of chemical shifts, peak multiplicities and $J$ values. $-{ }^{13} \mathrm{C}$ NMR spectra were determined with the same instrument at 75.4 MHz using the solvent peak as internal reference. - Elemental analyses of crystalline derivatives were carried out with a Leco CHNS 932 instrument. - For controlled-potential electrolyses a Hi-Tek potentiostat DT 2101, and a Hi-Tek wave generator PP RI, connected to a Philips recorder PM 8043, were used. The electrochemical cells were conventional two-compartment, three-electrode, home-built batch cells of the type illustrated elsewhere. ${ }^{[16]} \mathrm{H}$ Trp-OMe $\cdot \mathrm{HCl}$, Boc-Trp-OMe, H-His-OMe-2HCl, Boc-His-OMe and Bz-His-OMe are commercially available substances.

\section{Preparation of Tryptophan and Histidine Derivatives}

Synthesis of Tos-Trp-OMe (1a), Bz-Trp-OMe (1c) and Z(NO OMe (1e): $\mathrm{H}$-Trp-OMe, $\mathrm{HCl}(5 \mathrm{mmol})$ was dissolved in dichloromethane $\left(1 \mathrm{~mol} \mathrm{dm}^{-3}\right)$ and 2 equiv. of triethylamine was added; then, 1 equiv. of tosyl chloride, benzoyl chloride or $p$-nitrobenzyl chloroformate, respectively, was slowly added with vigorous stirring and cooling in an ice bath. After further stirring at $0{ }^{\circ} \mathrm{C}$ for $30 \mathrm{~min}$ and at room temperature for $3 \mathrm{~h}$, the solvent was evaporated and the residue partitioned between $200 \mathrm{~cm}^{3}$ of ethyl acetate and $100 \mathrm{~cm}^{3}$ of aqueous $\mathrm{KHSO}_{4}\left(1 \mathrm{~mol} \mathrm{dm}^{-3}\right)$, which was followed by washing with aqueous $\mathrm{KHSO}_{4} \quad\left(1 \mathrm{~mol} \mathrm{dm}^{-3}\right)$, aqueous $\mathrm{NaHCO}_{3}$ $\left(1 \mathrm{~mol} \mathrm{dm}^{-3}\right)$ and brine (3 times, $50 \mathrm{~cm}^{3}$ each). After drying with 
$\mathrm{MgSO}_{4}$, the extract was concentrated to dryness at reduced pressure to afford the respective $N^{\alpha}$-acyltryptophan methyl ester: 1a (1.428 g, $77 \%$ ), m.p. $128.0-129.0^{\circ} \mathrm{C}$ (from ethyl acetate $n$-hexane) (ref. $\left.{ }^{[17]} 128.5-130.0^{\circ} \mathrm{C}\right) ; 1 \mathrm{cc}(1.445 \mathrm{~g}, 90 \%)$, m.p. $107.5-109.0^{\circ} \mathrm{C}$ (from diethyl ether $/ n$-hexane) (ref. ${ }^{[17]} 110.8-112.5{ }^{\circ} \mathrm{C}$ ); and $1 \mathrm{e}$ $(1.564 \mathrm{~g}, 79 \%)$, m.p. $134-135{ }^{\circ} \mathrm{C}$ (from ethyl acetate $/ n$-hexane) (ref. ${ }^{[18]} 121.0-124.0^{\circ} \mathrm{C}$ ). $-\mathrm{C}_{20} \mathrm{H}_{19} \mathrm{~N}_{3} \mathrm{O}_{6}$ (397.39): calcd. C 60.45, $\mathrm{H} 4.82, \mathrm{~N} 10.57$; found $\mathrm{C} 60.59, \mathrm{H} 5.11, \mathrm{~N} 10.59$

Synthesis of Boc-Trp(Tos)-OMe (1b), Boc-Trp(Bz)-OMe (1d) and Boc-Trp $\left[\mathrm{Z}\left(\mathrm{NO}_{2}\right)\right]-\mathrm{OMe}$ (1f): These compounds were prepared by treating Boc-Trp-OMe (5 mmol) with tosyl chloride, benzoyl chloride or $p$-nitrobenzyl chloroformate, respectively, according to the procedure described by $\mathrm{Illi}^{[19]}$ to give $\mathbf{1 b}(2.313 \mathrm{~g}, 98 \%)$, m.p. $53-54{ }^{\circ} \mathrm{C}$ (from diethyl ether) $\left[\mathrm{C}_{24} \mathrm{H}_{28} \mathrm{~N}_{2} \mathrm{O}_{6} \mathrm{~S}\right.$ (472.56): calcd. $\mathrm{C}$ 61.01, H 5.97, N 5.92, S 6.78; found C 61.04, H 6.27, N 6.03, S 6.69]; 1d (1.815 g, 86\%), m.p. $101.0-103.0{ }^{\circ} \mathrm{C}$ (from ethyl acetate/ diethyl ether) $\left[\mathrm{C}_{24} \mathrm{H}_{26} \mathrm{~N}_{2} \mathrm{O}_{5}\right.$ (422.48): calcd. C 68.23, H 6.19, N 6.63; found $\mathrm{C} 68.28, \mathrm{H}$ 6.19, N 6.71]; and 1f $(2.038 \mathrm{~g}, 82 \%)$, m.p. $139-140{ }^{\circ} \mathrm{C}$ (from ethyl acetate/ $n$-hexane) $\left[\mathrm{C}_{25} \mathrm{H}_{27} \mathrm{~N}_{3} \mathrm{O}_{8}\right.$ (497.50): calcd. C 60.36, H 5.47, N 8.44; found C 60.29, H 5.48, N 8.41]

Synthesis of Tos-Trp(Tos)-OMe (1g): This compound was prepared by tosylation of $\mathrm{H}$-Trp(Tos)-OMe which in turn was obtained by acidolysis of $\mathbf{1 b}$.

Acidolysis of Boc-Trp(Tos)-OMe (1b): To 1 b $(3 \mathrm{mmol}) 9 \mathrm{~cm}^{3}$ of TFA was added and the solution left to stand for $1 \mathrm{~h}$. Excess TFA was removed by evaporation at reduced pressure and the residue triturated with diethyl ether and filtered to give H-Trp(Tos)OMe-TFA (1.341 g, 92\%), m.p. $152-153{ }^{\circ} \mathrm{C}$ (from diethyl ether). $-\mathrm{C}_{21} \mathrm{H}_{21} \mathrm{~N}_{2} \mathrm{O}_{6} \mathrm{SF}_{3}$ (486.47): calcd. C 51.85, H 4.35, N 5.75, S 6.59; found C 51.99, H 4.58, N 5.92, S 6.69 .

Tosylation of H-Trp(Tos)-OMe,TFA: The procedure described for the preparation of 1a was followed by substituting H-Trp(Tos)OMe-TFA $(2.5 \mathrm{mmol})$ for $\mathrm{H}-\mathrm{Trp}-\mathrm{OMe} \cdot \mathrm{HCl}$ to give $\mathbf{1 g}(1.131 \mathrm{~g}$, $86 \%$ ), m.p. $102-104{ }^{\circ} \mathrm{C}$ (from diethyl ether $/ n$-hexane). $\mathrm{C}_{26} \mathrm{H}_{26} \mathrm{~N}_{2} \mathrm{O}_{6} \mathrm{~S}_{2}$ (526.63): calcd. C 59.30, H 4.97, N 5.32, S 12.17; found $\mathrm{C} 58.95, \mathrm{H} 5.14, \mathrm{~N} 5.60, \mathrm{~S} 11.98$.

Synthesis of Bz-Trp(Bz)-OMe (1h): The procedure described above for the synthesis of $\mathbf{1 b}, \mathbf{1 d}$ and $\mathbf{1 f}$ was followed by substituting $\mathrm{H}$ Trp-OMe $\cdot \mathrm{HCl}(5 \mathrm{mmol})$ for Boc-Trp-OMe and treating it with 2 equiv. of benzoyl chloride to give $\mathbf{1 h}(1.534 \mathrm{~g}, 72 \%)$, m.p. 195.0-196.0 ${ }^{\circ} \mathrm{C}$ (dichloromethane/ $n$-hexane). $\quad-\mathrm{C}_{26} \mathrm{H}_{22} \mathrm{~N}_{2} \mathrm{O}_{4}$ (426.47): calcd. C 73.23, H 5.20, N 6.57; found C 73.43, H 5.24, N 6.60 .

Synthesis of Tos-His-OMe (2a): This compound was obtained by controlled-potential electrolysis and also by $\mathrm{Mg} / \mathrm{MeOH}$-mediated cleavage of $\mathbf{2} \mathbf{g}$ as described below.

Synthesis of $\mathbf{Z}\left(\mathbf{N O}_{2}\right)$-His-OMe (2e): $\mathrm{H}-\mathrm{His}(\mathrm{HCl})-\mathrm{OMe} \cdot \mathrm{HCl} \quad(1$ mmol) was dissolved in dichloromethane $\left(0.2 \mathrm{~mol} \mathrm{dm}^{-3}\right)$ and 4 equiv. of triethylamine was added followed by slow addition of 1 equiv. of $p$-nitrobenzyl chloroformate under vigorous stirring and cooling in an ice bath. The reaction mixture was then concentrated at reduced pressure and the residue chromatographed through a silica column and using chloroform/methanol as the eluent to give 2e $(0.261 \mathrm{~g}, 75 \%)$, m.p. $150.5-152.0{ }^{\circ} \mathrm{C}$ (from dichloromethane/ diethyl ether). $-\mathrm{C}_{15} \mathrm{H}_{16} \mathrm{~N}_{4} \mathrm{O}_{6}$ (348.31): calcd. $\mathrm{C} 51.72, \mathrm{H} 4.63, \mathrm{~N}$ 16.09; found C 51.37, $\mathrm{H} 4.87, \mathrm{~N} 16.05$.

Synthesis of Boc-His(Tos)-OMe (2b), Boc-His(Bz)-OMe (2d) and Boc-His[Z( $\left.\left(\mathrm{NO}_{2}\right)\right]-\mathrm{OMe}$ (2f): Boc-His-OMe $(5 \mathrm{mmol})$ was dissolved in chloroform $\left(0.2 \mathrm{~mol} \mathrm{dm}^{-3}\right)$ and 1 equiv. of triethylamine was added; then, 1 equiv. of tosyl chloride, benzoyl chloride or $p$-nitrobenzyl chloroformate, respectively, was slowly added with vigorous stirring and cooling in an ice bath. After further stirring at $0{ }^{\circ} \mathrm{C}$ for $30 \mathrm{~min}$ and at room temperature for $2 \mathrm{~h}, 30 \mathrm{~cm}^{3}$ of chloroform was added to the reaction mixture and the solution washed with water, $\mathrm{KHSO}_{4}\left(1 \mathrm{~mol} \mathrm{dm}^{-3}\right)$ and brine ( 3 times, $50 \mathrm{~cm}^{3}$ each). After drying with $\mathrm{MgSO}_{4}$, the extract was concentrated to dryness at reduced pressure and the residue submitted to eventual recrystallisation to afford the required product; $2 \mathbf{b}(2.052 \mathrm{~g}, 97 \%)$ was obtained as an oil; $2 \mathbf{d}\left(1.865 \mathrm{~g}, 100 \%\right.$ ), m.p. $104.5-105.5^{\circ} \mathrm{C}$ (from $n$ hexane) and 2 f $(2.195 \mathrm{~g}, 98 \%)$, m.p. $72.0-73.5^{\circ} \mathrm{C}$ (from diethtyl ether/petroleum ether). $-\mathbf{2 d}: \mathrm{C}_{19} \mathrm{H}_{23} \mathrm{~N}_{3} \mathrm{O}_{5}$ (373.41): calcd. C 61.12, $\mathrm{H}$ 6.21, N 11.25; found C 60.92, H 6.29, N 11.05. - 2f: $\mathrm{C}_{20} \mathrm{H}_{24} \mathrm{~N}_{4} \mathrm{O}_{8}$ (448.43): calcd. C 53.57, H 5.39, N 12.49; found C 53.81, H 5.41, N 12.39

Synthesis of Tos-His(Tos)-OMe (2g) and Bz-His(Bz)-OMe (2h): The procedure described above was followed by substituting H-His$\mathrm{OMe} \cdot 2 \mathrm{HCl}(5 \mathrm{mmol})$ for Boc-His-OMe and treating it with 2 equiv. of tosyl chloride or benzoyl chloride, respectively, in the presence of 4 equiv. of triethylamine to give $2 \mathrm{~g}$ (1.980 g, 83\%), m.p. 168-169 ${ }^{\circ} \mathrm{C}$ (from dichloromethane $/ n$-hexane) (ref. ${ }^{[20]} 183-185 \quad{ }^{\circ} \mathrm{C}$ ) $\left[\mathrm{C}_{21} \mathrm{H}_{23} \mathrm{~N}_{3} \mathrm{O}_{6} \mathrm{~S}_{2}\right.$ (477.56): calcd. C 52.82, H 4.85, N 8.80, S 13.42; found C 52.71, H 5.07, N 9.17, S 13.24] and 2 h (1.376 g, 73\%), m.p. $126.5-127.5^{\circ} \mathrm{C}$ (from ethyl acetate $/ n$-hexane).

Controlled-Potential Electrolysis of Tryptophan and Histidine SideChain Protecting Groups

Electrolysis of Boc-Trp(Tos)-OMe (1b), Boc-Trp(Bz)-OMe (1d) and Boc-Trp[Z( $\left.\left(\mathrm{NO}_{2}\right)\right]-O M e$ (1f): The two compartments of a controlled-potential electrolysis cell were filled with acetonitrile containing $\mathrm{Et}_{4} \mathrm{NCl}\left(0.1 \mathrm{~mol} \mathrm{dm}^{-3}\right)$ as supporting electrolyte and $\mathrm{Et}_{3} \mathrm{NHCl}\left(0.03 \mathrm{~mol} \mathrm{dm}^{-3}\right)$ as proton donor. 1b $(1 \mathrm{mmol})$, 1d (1 $\mathrm{mmol})$, or $1 \mathrm{f}(1 \mathrm{mmol})$ was added to the cathodic compartment and a cyclic voltammogram recorded at a sweep rate of $100 \mathrm{mV} \mathrm{s}^{-1}$ in order to measure the corresponding first peak potential. The potential was adjusted to a value corresponding to $50 \mathrm{mV}$ lower than the peak potential measured and the apparatus switched on. When the flow of the current was almost zero, the reaction mixture (catholyte) was transferred to a round-bottomed flask and the solvent evaporated at reduced pressure. The residue was partitioned between $100 \mathrm{~cm}^{3}$ of diethyl ether and $50 \mathrm{~cm}^{3}$ of aqueous $\mathrm{KHSO}_{4}$ $\left(1 \mathrm{~mol} \mathrm{dm}^{-3}\right)$. The organic layer was then washed with aqueous $\mathrm{KHSO}_{4}\left(1 \mathrm{~mol} \mathrm{dm}^{-3}\right)$, aqueous $\mathrm{NaHCO}_{3}\left(1 \mathrm{~mol} \mathrm{dm}^{-3}\right)$ and brine (3 times, $30 \mathrm{~cm}^{3}$ each), and dried with $\mathrm{MgSO}_{4}$. Concentration at reduced pressure gave the Boc-Trp-OMe derivatives in yields of $84 \%$ (0.267 g), 77\% (0.245 g) and 74\% (0.235 g), respectively.

Electrolysis of Tos-Trp(Tos)-OMe (1g) and Bz-Trp(Bz)-OMe (1h): The procedure described above was followed with $\mathbf{1 g}(1 \mathrm{mmol})$ and 1h $(1 \mathrm{mmol})$ as the substrate to give 1a $(0.275 \mathrm{~g}, 74 \%)$ and 1c $(0.254 \mathrm{~g}, 72 \%)$, respectively.

Electrolysis of Boc-His(Tos)-OMe (2b), Boc-His(Bz)-OMe (2d) and Boc-His $\left[\mathbf{Z}\left(\mathbf{N O}_{2}\right)\right]-O M e$ (2f): The procedure described above was followed using $\mathbf{2 b}(1 \mathrm{mmol}), \mathbf{2} \mathbf{d}(1 \mathrm{mmol})$ and $\mathbf{2 f}(1 \mathrm{mmol})$ as substrates, but the residue obtained from concentration of the catholyte at reduced pressure was partitioned between $100 \mathrm{~cm}^{3}$ of chloroform and $50 \mathrm{~cm}^{3}$ of aqueous $\mathrm{NaHCO}_{3}\left(1 \mathrm{~mol} \mathrm{dm}^{-3}\right)$. The organic layer was then washed with aqueous $\mathrm{NaHCO}_{3}\left(1 \mathrm{~mol} \mathrm{dm}{ }^{-3}\right)$ and brine ( 3 times, $30 \mathrm{~cm}^{3}$ each), and dried with $\mathrm{MgSO}_{4}$. The solvent was evaporated at reduced pressure and the residue chromatographed on a silica-gel column; chloroform/methanol was used as the eluent to give the Boc-His-OMe derivatives in yields of $63 \%$ $(0.169 \mathrm{~g}), 87 \%(0.234 \mathrm{~g})$ and $70 \%(0.188 \mathrm{~g})$, respectively. 
Electrolysis of Tos-His(Tos)-OMe (2g) and Bz-His(Bz)-OMe (2h): The procedure described above was followed with $\mathbf{2 g}(1 \mathrm{mmol})$ and 2h (1 mmol) as substrates to give 2a (0.294 g, 81\%), m.p. 176-178 ${ }^{\circ} \mathrm{C}$ (from methanol/diethyl ether) $\left[\mathrm{C}_{14} \mathrm{H}_{18} \mathrm{ClN}_{3} \mathrm{O}_{4} \mathrm{~S}\right.$ (359.83): calcd. C 46.73, H 5.04, N 11.67, S 8.91; found C 46.57, H 5.12, N 11.75, S 9.05) and 2c (0.238 g, 87\%), respectively.

Magnesium in Methanol [Mg/MeOH] Cleavage of Tryptophan and Histidine Side-Chain Protecting Groups

$\mathrm{Mg} / \mathrm{MeOH}$ Cleavage of Boc-Trp(Tos)-OMe (1b) and Boc-Trp(Bz)OMe (1d): Compound $\mathbf{1 b}(1 \mathrm{mmol})$ or $\mathbf{1 d}(1 \mathrm{mmol})$ was added to a suspension of magnesium powder $(1 \mathrm{mmol})$ in dry methanol $\left(8 \mathrm{~cm}^{3}\right)$. The resulting mixture was sonicated for $40 \mathrm{~min}$ at room temperature until TLC on silica ( $n$-hexane/ethyl acetate, $3: 2)$ indicated that all the starting material had been consumed. The reaction was quenched by addition of saturated aqueous $\mathrm{NH}_{4} \mathrm{Cl}\left(10 \mathrm{~cm}^{3}\right)$ and extracted three times with ethyl acetate $\left(30 \mathrm{~cm}^{3}\right)$. The organic layer was dried with $\mathrm{MgSO}_{4}$ and concentrated to dryness to give Boc-Trp-OMe in yields of 98\% (0.312 g) and 93\% (0.296 g), respectively.

$\mathrm{Mg} / \mathrm{MeOH}$ Cleavage of Tos-Trp(Tos)-OMe (1g) and Bz-Trp(Bz)OMe (1h): The procedure described above was followed with $\mathbf{1 g}(1$ $\mathrm{mmol})$ and $\mathbf{1 h}(1 \mathrm{mmol})$ as the substrate to give $\mathbf{1 a}(0.334 \mathrm{~g}, 90 \%)$ and $1 \mathrm{c}(0.286 \mathrm{~g}, 81 \%)$, respectively.

Mg/MeOH Cleavage of Boc-His(Tos)-OMe (2b) and Boc-His(Bz)OMe (2d): The procedure described above was followed with $\mathbf{2 b}$ (1 mmol) and $2 \mathbf{d}(1 \mathrm{mmol})$ as the substrate. When TLC on silica (chloroform/methanol, 6:1) indicated that all the starting material had been consumed, the reaction was quenched by addition of saturated aqueous $\mathrm{NH}_{4} \mathrm{Cl}\left(10 \mathrm{~cm}^{3}\right)$ and extracted three times with chloroform $\left(30 \mathrm{~cm}^{3}\right)$. The organic layer was then washed with $\mathrm{NaHCO}_{3}\left(1 \mathrm{~mol} \mathrm{dm}^{-3}\right)$ and brine (3 times, $30 \mathrm{~cm}^{3}$ each), and dried with $\mathrm{MgSO}_{4}$ to give Boc-His-OMe in yields of $83 \%(0.223 \mathrm{~g})$ and $91 \%(0.245 \mathrm{~g})$, respectively.

$\mathrm{Mg} / \mathrm{MeOH}$ Cleavage of Tos-His(Tos)-OMe (2g) and $\mathrm{Bz}-\mathrm{His}(\mathrm{Bz})-$ OMe (2h): The procedure described above was followed with $\mathbf{2 g}$ (1 $\mathrm{mmol})$ and $\mathbf{2 h}(1 \mathrm{mmol})$ as the substrate to give $\mathbf{2 a}(0.291 \mathrm{~g}, 89 \%)$ and $2 \mathrm{c}(0.227 \mathrm{~g}, 83 \%)$, respectively.

Mercury-Activated Aluminum [Al(Hg)] Cleavage of Tryptophan and Histidine Side-Chain Protecting Groups

$\mathrm{Al}(\mathrm{Hg})$ Cleavage of Boc-Trp[Z(NO$)]-O M e$ (1f): Finely cut aluminum foil $(10 \mathrm{mmol})$ was stirred with a few drops of mercury for 30 min under a stream of nitrogen. 1f $(0.5 \mathrm{mmol})$, dissolved in diethyl ether $(10 \mathrm{~mL})$ with water $(1 \%)$, was added. After $2 \mathrm{~h}$, when most of the aluminum had dissolved and TLC indicated only minor amounts of 1f, more mercury-treated aluminum foil ( $5 \mathrm{mmol})$ was added and left to react for a further $2 \mathrm{~h}$. The greyish solid material was then filtered off with suction and thoroughly rinsed with diethyl ether. Concentration of the yellow filtrate gave an oil that was dissolved in chloroform and filtered to remove all dark insoluble particles. Concentration to dryness at reduced pressure gave BocTrp-OMe $(0.153 \mathrm{~g}, 96 \%)$.

$\mathrm{Al}(\mathrm{Hg})$ Cleavage of Boc-His(Bz)-OMe (2d) and Boc-His[Z( $\left.\left(\mathrm{NO}_{2}\right)\right]-$ OMe (2f): The procedure described above was followed with 2 d
$(0.5 \mathrm{mmol})$ and $2 \mathrm{f}(0.5 \mathrm{mmol})$ as the substrate to give Boc-HisOMe in yields of $87 \%(0.117 \mathrm{~g})$ and $94 \%(0.126 \mathrm{~g})$, respectively.

$\mathbf{A l}(\mathbf{H g})$ Cleavage of $\mathbf{B z}-\mathrm{His}(\mathrm{Bz})-\mathrm{OMe}(\mathbf{2 h})$ : The procedure described above was followed with $\mathbf{2 h}(0.5 \mathrm{mmol})$ as the substrate to give $\mathbf{2 c}$ in a $85 \%(0.116 \mathrm{~g})$ yield.

2-(Diethylamino)ethylamine-Induced Aminolysis of Tryptophan and Histidine Derivatives

Aminolysis of Boc-Trp(Bz)-OMe (1d) and Bz-Trp(Bz)-OMe (1h): The reactions were carried out according to the procedure described by Ragnarsson et al. ${ }^{[13]}$ with $\mathbf{1 d}(1 \mathrm{mmol})$ and $\mathbf{1 h}(1 \mathrm{mmol})$ to give Boc-Trp-OMe $(0.293 \mathrm{~g}, 92 \%)$ and $1 \mathrm{c}(0.332 \mathrm{~g}, 94 \%)$, respectively.

Aminolysis of Boc-His(Bz)-OMe (2d) and Bz-His(Bz)-OMe (2h): The same procedure as above was followed with $\mathbf{2 d}(1 \mathrm{mmol})$ and 2h (1 mmol), as substrates to give Boc-His-OMe $(0.169 \mathrm{~g}, 63 \%)$ and 2c $(0.246 \mathrm{~g}, 90 \%)$, respectively.

[1] E. Schroder, K. Lubke, The Peptides, Academic Press, New York, 1965, vol. 1.

[2] E. Gross, J. Meienhofer, The Peptides, Analysis, Synthesis, Biology, Academic Press, New York, 1981, vol. 3.

[3] Y. B. Alakhov, A. A. Kiryushkin, V. M. Lipkin, J. Chem. Soc., Chem. Commun. 1970, 406-407.

[4] S. Terada, A. Kawabata, N. Mitsuyasu, H. Aoyagi, N. Izumiya, Bull. Chem. Soc. Jpn. 1978, 51, 3409-3410.

[5] J. C. Sheehan, K. Hasspacher, Y. L. Yeh, J. Am. Chem. Soc. 1959, 81,6086

[6] B. Nyasse, L. Grehn, H. L. S. Maia, L. S. Monteiro, U. Ragnarsson, J. Org. Chem. 1999, 64, 7135-7140.

[7] M. Largeron, B. Farrell, J. F. Rousseau, M. B. Fleury, P. Potier, R. H. Dodd, Tetrahedron Lett. 2000, 41, 9403-9406.

[8] B. Nyasse, L. Grehn, U. Ragnarsson, Chem. Commun. 1997, $1017-1018$

[9] T. W. Greene, P. G. M. Wuts, Protective Groups in Organic Chemistry, 3rd ed., Wiley, New York, 1999, chapter 7.

${ }^{[10]}$ P. J. Kocienski, Protecting Groups, Thieme, New York, 1994, p. $209-212$

${ }^{[11]}$ H. L. S. Maia, L. S. Monteiro, F. Degerbeck, L. Grehn, U. Ragnarsson, J. Chem. Soc., Perkin Trans. 2 1993, 495-500.

${ }^{[12]}$ H. L. S. Maia, M. J. Medeiros, M. I. Montenegro, D. Pletcher, J. Chem. Soc., Perkin Trans. 2 1988, 409-412.

${ }^{[13]}$ L. Grehn, K. Gunnarsson, U. Ragnarsson, Acta Chem. Scand., Ser. $B$ 1987, $41,18-23$.

${ }^{[14]}$ L. Grehn, H. L. S. Maia, L. S. Monteiro, M. I. Montenegro, U. Ragnarsson, J. Chem. Res. 1991, $(S)$ 144-145, $(M)$ $1501-1519$

${ }^{[15]}$ U. Ragnarsson, L. Grehn, H. L. S. Maia, L. S. Monteiro, J. Chem. Res. 2000, $(S)$ 6-7, $(M) 128-136$.

${ }^{[16]}$ L. Grehn, K. Gunnarsson, H. L. S. Maia, M. I. Montenegro, L. Pedro, U. Ragnarsson, J. Chem. Res. 1988, (S) 399, (M) 3081-3093.

[17] T. Shono, Y. Matsumura, T. Tsubata, K. Uchida, T. Kanazawa, K. Tsuda, J. Org. Chem. 1984, 49, 3711-3716.

${ }^{[18]}$ I. Z. Siemion, Bull. Acad. Polon. Sci., Ser. Sci. Chim. 1965, $13,39-42$.

${ }^{[19]}$ V. O. Illi, Synthesis 1979, 136.

${ }^{[20]}$ G. L. Schmir, W. M. Jones, L. A. Cohen, Biochemistry 1965, $4,539-545$.

Received November 28, 2000

[O00614] 